University of Thi-Qar Journal Vol. 13 No.3 SEP 2018

Web Site: https://jutq.utq.edu.iq/index.php/main

Email: journal@jutq.utq.edu.iq

\title{
The Histological structure and Biometric in Adrenal gland \\ of Buffalo Bubalus bubalis at South of Iraq \\ Layla Alhasan
}

Department of Biology, College of Education for Pure

Sciences, Thi-Qar University, Thi-Qar, Iraq

Email: layla@eps.utq.edu.iq

\begin{abstract}
The study aimed to reveal the histological investigation of structural and components and determined the biometric measurements of adrenal glands in buffalo. The study has been performed on six pairs of buffalo's glands of both sexes which were collected from slaughter house in AlNasiriya city. Results have shown structural features of components of gland which were typical connective tissue capsule and cortex which consist of zona glomerulosa, zona fasciculate contained two types of cells and zona reticularis which is interfering with medulla cells. As well as biometric measurement have been reported the thickness ratio of the components of the glands,capsule,cortex(zona glomerulosa,zona fasciculate and zona reticularis) and medulla thickness which were $8.27 \%, 56.95 \% 15.56 \% ; 27.48 \% ; 13.90 \%, 34.76 \%$ ) respectively. The study has been concluded that cortex form more half of the gland and medulla formed one third of gland as well as zona fasciculate was width zone and subdivided in to two parts, zona reticularis was narrowest zone .The present study is first reported of adrenal glands in buffalo at south of Iraq.
\end{abstract}

Keywords: Buffalo, adrenal gland, Biometric measurements, Coretx, Medulla . 


\section{Introduction}

The adrenal gland is composed of two distinct portions which are outer cortex (mesodermal origin) and inner medulla (neuro-ectodermal origin)(Bank,1993 and Delman,1993).The adrenal cortex is subdivided into three distinct zones of epithelial (Junqueira et al.,1995 )whereas Bacha and Wood, (1990) mentioned that cortex is subdivided into four zones of epithelial cells. The cortex has three zones, which are not sharply separated from each other. The zona glomerulosa is outer zone which its cells are arranged in ovoid groups (Colby et al.,1992).These cells in carnivores and horse are arranged into arcs due to called zona arcuata (Tanyolac,1993 ; Prasad \&Shinha,1981).Sinusoidal capillaries are present among cells of zona glomerulosa (Difiore,1981). The zona fasciculate, the widest zone of adrenal cortex arc consist of radially arranged cords of cuboidal or columnar cells(Karadag et al.,1995).These cells characterized with vacuolated appearance and the presence of high proportion lipid droplet (Temur et al.,2007). The zona reticularis consist of cells disposed as freely anastomosing cords. The cells are rough the same in morphologic features as the cells of the zona fasciculate, but their nuclei and cytoplasm have darker staining (Junquira et al., 1995 and Tanylac, 1993). Medulla consist of chromaffin cells which are arranged in groups.thier cytoplasm is relatively clear and have brown granules which represented epinephrine and nor epinephrine (Steven \& Lowe, 1991; Dellman, 1993). There are two types of chromaffin and granules of epinephrine cells which are smaller and dense compared to epinephrine cells (Gude et al., 1982). Also medulla contained sympathetic ganglion cells arranged singly in groups. They have characteristic vesicular nucleus, sinusoidal capillaries are present in medulla which drain into medullary veins (Difiore, 1981). The neither cells secreting nor epinephrine have peripheral location while those secreting epinephrine are central (Williams and Warwick, 1995). There are collagen fibrils and fibroblasts in the stroma of the medulla and rarely macrophages (Delman, 1993). Innervations of adrenal medulla is sympathetic where as there is no parasympathetic innervations also adrenal glands have more autonomous innervations than the other gland (Petorak, 1984).This study 
Web Site: https://jutq.utq.edu.iq/index.php/main

Email: journal@jutq.utq.edu.iq

aims to describe of histological exploration and determined of parameter of adrenal gland in buffalo due to the seldom investigations which is concerning within this field.

\section{Material Methods}

In this study, twelve adrenal glands were collected from six adult buffaloes (female and male).The buffaloes were slaughter within abattoir in Al-Nassirya province. The specimens have been taken and kept within clean container. For light microscope examination, $10 \%$ formalin has used to fix the tissue. After fixation, the specimens have been prepared to make histological sections and stained with routine haematoxylin and eosin according to (Luna, 1965). Then routine histological sectioning has been performed in Al-Nassirya hospital. Biometric measurements were determined by ocular micrometer for component zones of glands. The biometric measurements include the following parameters: 1- The height of capsules.2- The height of aructa zones of cortex (zona glomerularis, zona fasciculate and zona reticularius). 3- The height of medulla by ocular lens micrometer. Photographs were taken with digital camera has been done in Education Faculty for Pure Sciences, Thi-Qar university.

\section{Results}

The present study revealed that adrenal glands consist of cortex and medulla .Cortex was covered by typical capsule of dense collagenous tissue (Fig.1).The study reported that the thickness mean of capsule which attained to (250) micrometer. The cortex composed of three distinct zones which distinguished with light microscopically investigation as well as cortex formed $56.95 \%$ of gland. The first zone was zona glomerularis which their cells arranged into circular clusters with irregular organization. Also their nuclei were longitudinal -a round shape with slightly dark stain (Fig, 1.2, 3). The thickness of this zone was reported about (470) micrometer, which was formed $15.56 \%$ of cortex. The second zone was appeared which zona fasciculate that can be differentiated into two types of cells. First type lies on the upper part of the zone which arranged into columns cords and each column has two 


\section{University of Thi-Qar Journal Vol. 13 No.3 SEP 2018 \\ Web Site: https://jutq.utq.edu.iq/index.php/main \\ Email: journal@jutq.utq.edu.iq}

cells width, they were very closed together. Their nuclei are round and dark stain. So that they appeared also central in position and surrounded with little amount of cytoplasm with slightly dark stain mean while lower part of this zone, cells arranged into columns cords which oriented in radial directions, each columns has contained one cells in width therefore, cells appeared distance regular array cords. These cells contained nuclei in lateral position and the cytoplasm take relatively light stain and sometimes appear as vacuoles. Foamy cells were present between the cells of this part of zone which appeared as vacuolated cells. Sinusoidal capillaries were abundant of cells (Fig.4, 5).The mean of thickness was reported about (830) micrometer which formed $27.48 \%$ of cortex. The third zone was observed that zona reticularis,this zone was difficult separated from medulla as well as close interfering and surrounding with cells of medulla. The cells were appeared anatomizing form which oriented in different directions, their nuclei central position as well as took dark stain. These cells are irregular arranged which appeared as reticular organization (Fig 6, 7). The mean of this zona thickness (420 micrometer) which formed $13.90 \%$ of cortex. Medulla represent the internal position of gland which surrounded with cells of cortex also formed $34.76 \%$ from gland. Medulla mainly composed from two types cells. First type cells were peripheral position and the other cells were central position, these two types cells arranged in circular groups so as somewhat closely similar to each other which difficult to distinguish, exception. That the difference was in peripheral cells were light stain where as cells in central took dark stain. Also in medulla can be observed sympathetic ganglion cells which arranged in groups between medullary cells, they have vesicular nucleus (Fig 6, 8, 9). Medulla characterized by the present of abundant sinusoidal capillaries which found between two types of medulla. in addition the present of highly blood vessels in a various size, as well as capsule thickness was reported about $8.27 \%$ from whole gland. 
University of Thi-Qar Journal Vol. 13 No.3 SEP 2018

Web Site: https://jutq.utq.edu.iq/index.php/main

Email: journal@jutq.utq.edu.iq

Biometric Measurements of Adrenal Gland Components and Ratio

\begin{tabular}{|l|l|l|}
\hline Structural & $\begin{array}{l}\text { Thickness- } \\
\text { micrometer- }\end{array}$ & $\begin{array}{l}\text { Ratio of thickness for } \\
\text { gland \% }\end{array}$ \\
\hline Capsule & $250^{-+}$ & 8.27 \\
\hline Cortex & $1720^{-+}$ & 56.95 \\
\hline Zona glomerolosa & $470^{-+}$ & 15.56 \\
\hline Zona fasciculate & $830^{-+}$ & 27.48 \\
\hline Zona reticularis & $420^{-+}$ & 13.90 \\
\hline Medulla & $1050^{-+}$ & 34.76 \\
\hline
\end{tabular}

Biometric Measurements of Cortex Adrenal Gland Components and Ratio

\begin{tabular}{|l|l|l|}
\hline Structural & $\begin{array}{l}\text { Thickness- } \\
\text { micrometer }\end{array}$ & $\begin{array}{l}\text { Ratio of thickness for } \\
\text { cortex gland \% }\end{array}$ \\
\hline Zona glomerolosa & $470^{-+}$ & 27.32 \\
\hline Zona fasciculate & $830^{-+}$ & 48.25 \\
\hline Zona reticularis & $420^{-+}$ & 24.41 \\
\hline
\end{tabular}

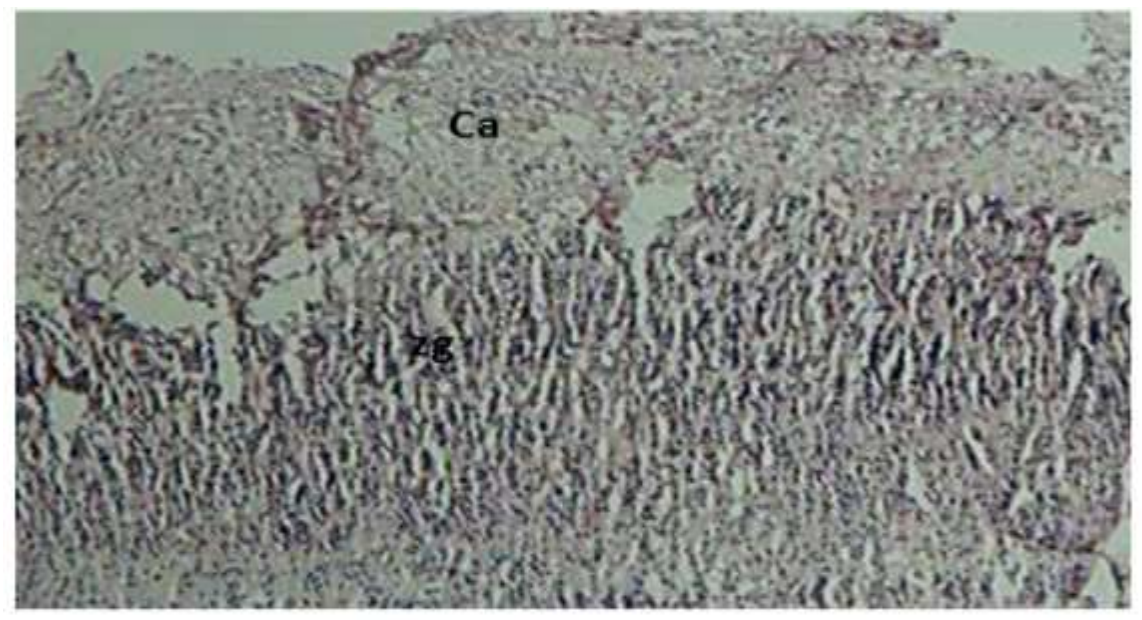

Fig (1): Transverse section of capsule ( ca ) and zona glomerlosa (zg) adrenal gland $(100 \mathrm{x}) . \mathrm{H} \& \mathrm{E}$ staining 
University of Thi-Qar Journal Vol. 13 No.3 SEP 2018

Web Site: https://jutq.utq.edu.iq/index.php/main

Email: journal@jutq.utq.edu.iq

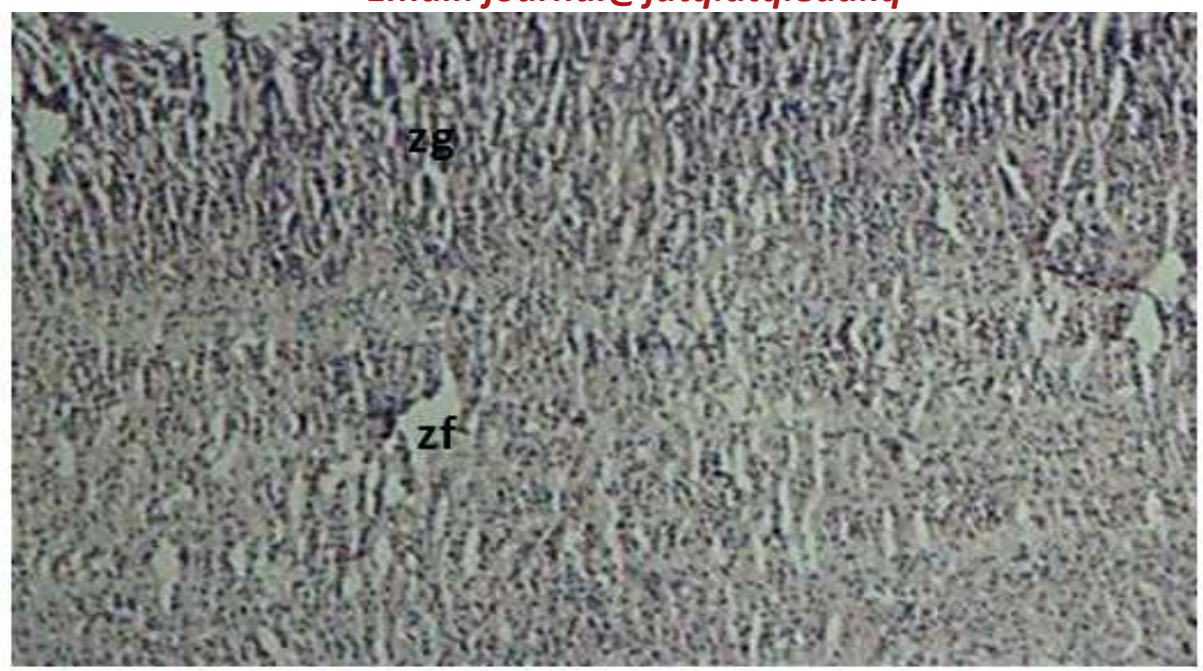

Fig (2): Transverse section of zona glomerlosa (zg) and zona fasciculate (zf) adrenal gland $(100 \mathrm{x}) . \mathrm{H} \& \mathrm{E}$ stain

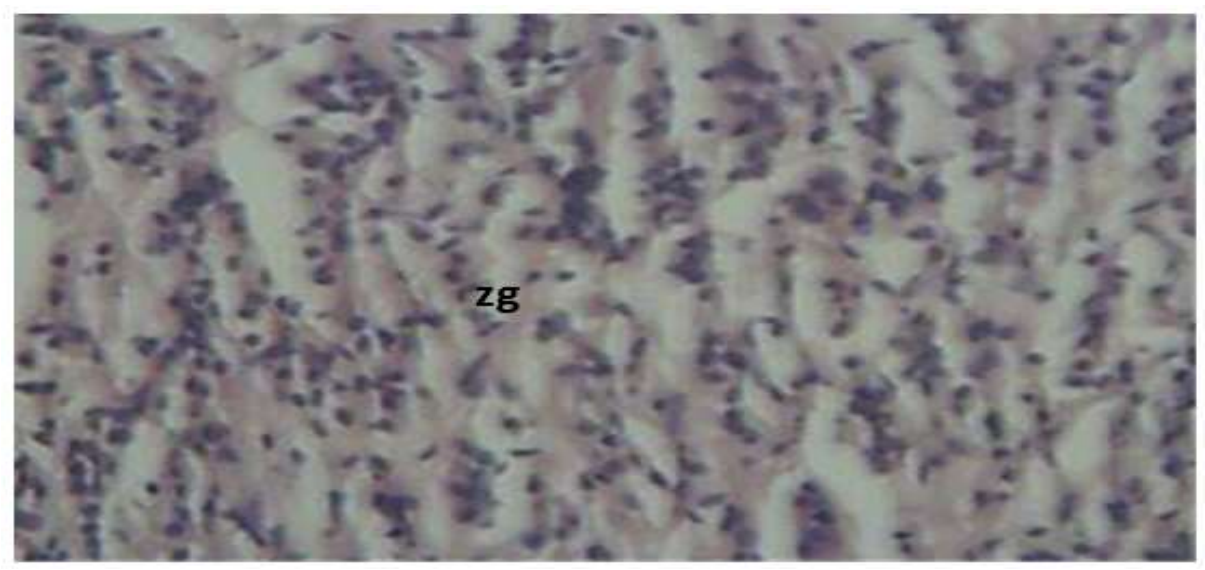

Fig (3): Transverse section of zona glomerlosa (zg) adrenal gland (400 x) H\&E staining. 
University of Thi-Qar Journal Vol. 13 No.3 SEP 2018

Web Site: https://jutq.utq.edu.iq/index.php/main

Email: journal@jutq.utq.edu.iq

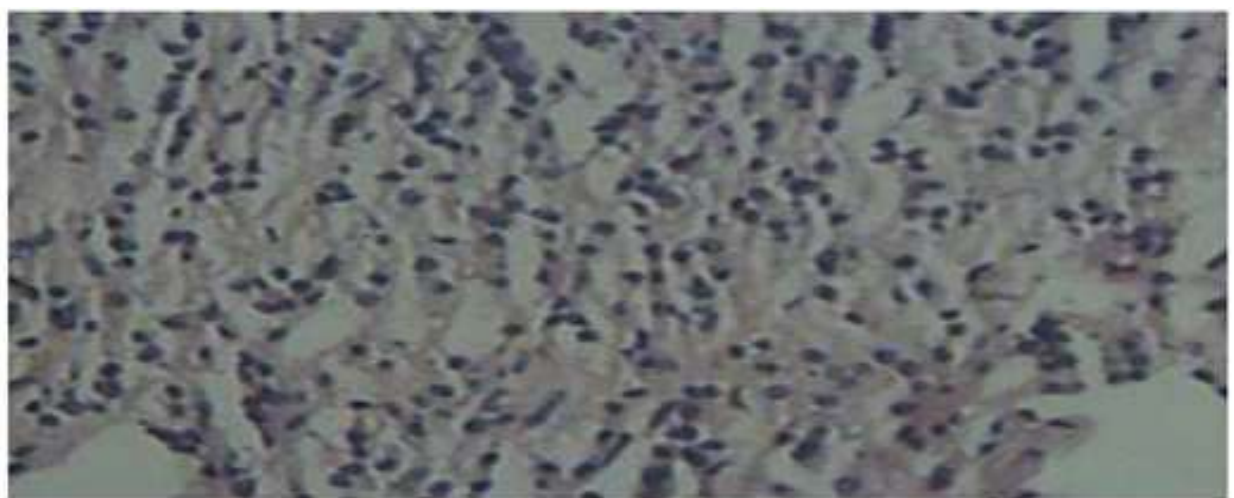

Fig (4): Transverse section of first layer of fasciculate zona adrenal gland (400 $\mathrm{x}) . \mathrm{H} \& \mathrm{E}$ staining.

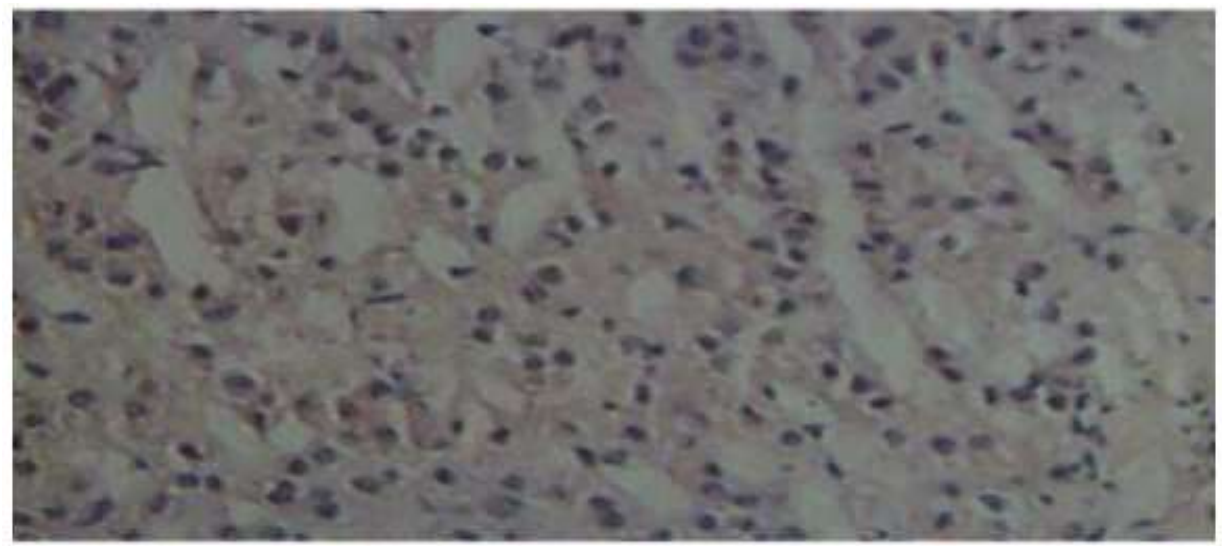

Fig (5): Transverse section of second layer of fasciculate zona adrenal gland H\&E staining (400x). 
University of Thi-Qar Journal Vol. 13 No.3 SEP 2018

Web Site: https://jutq.utq.edu.iq/index.php/main

Email: journal@jutq.utq.edu.iq

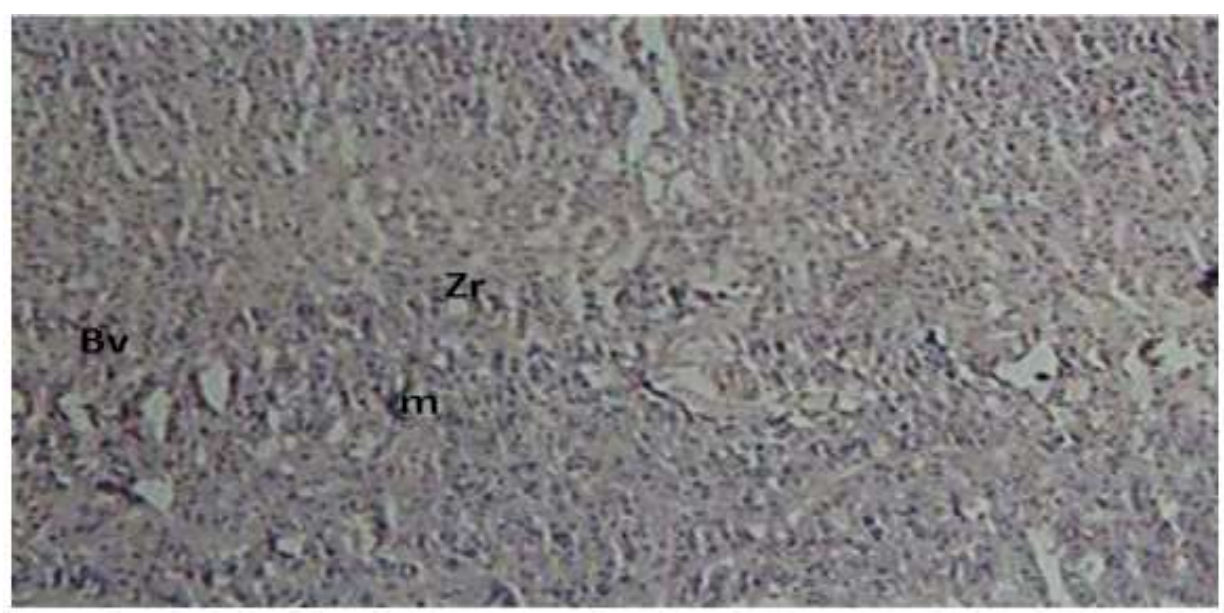

Fig (6): Transverse section of first layer of zona reticular is (zr) and medulla adrenal gland,bv=blood vessel (100 x). H\&E staining.

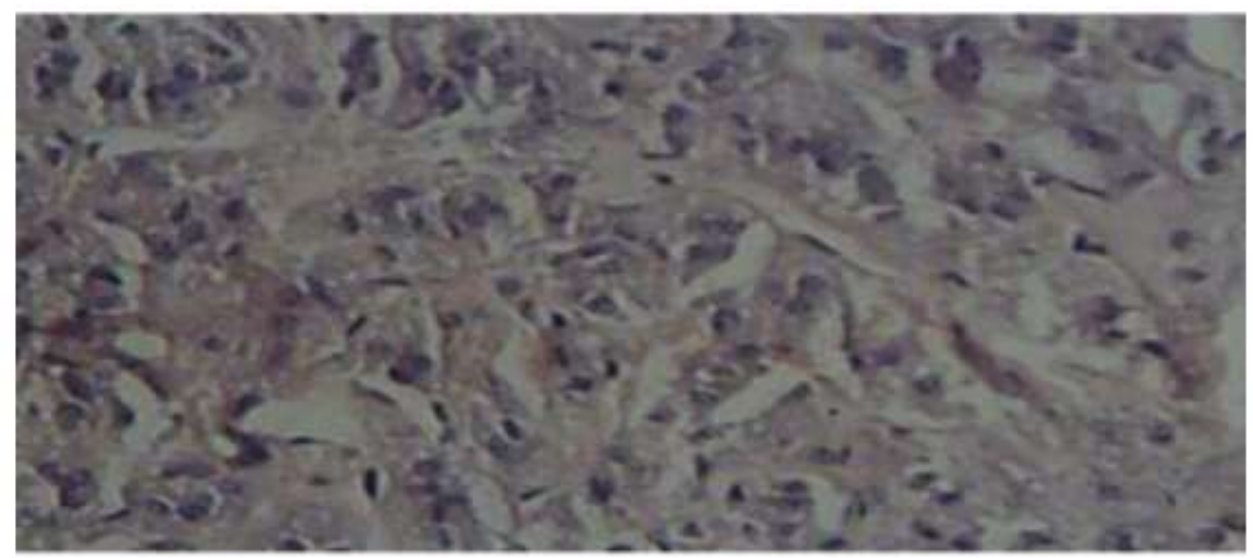

Fig (7): Transverse section of of reticularis zona adrenal gland $(400 \mathrm{x}) . \mathrm{H} \& \mathrm{E}$ staining. 
University of Thi-Qar Journal Vol. 13 No.3 SEP 2018

Web Site: https://jutq.utq.edu.iq/index.php/main

Email: journal@jutq.utq.edu.iq

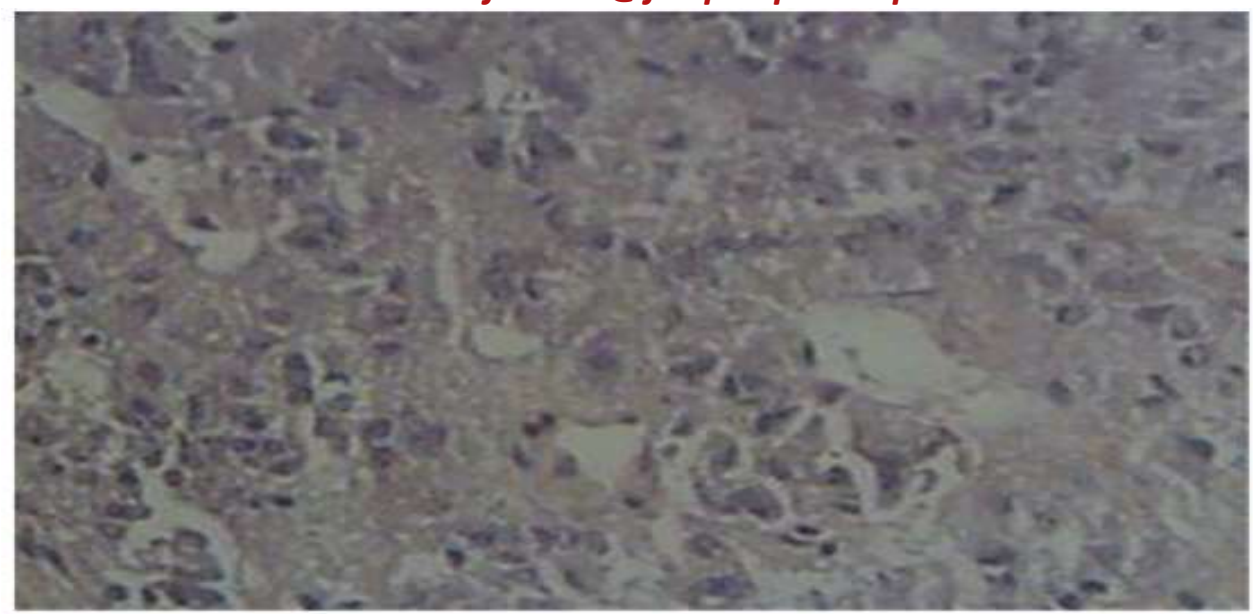

Fig (8): Transverse section of first layer of medulla adrenal gland showed types cells arranged in circular groups (400 x). H\&E staining.

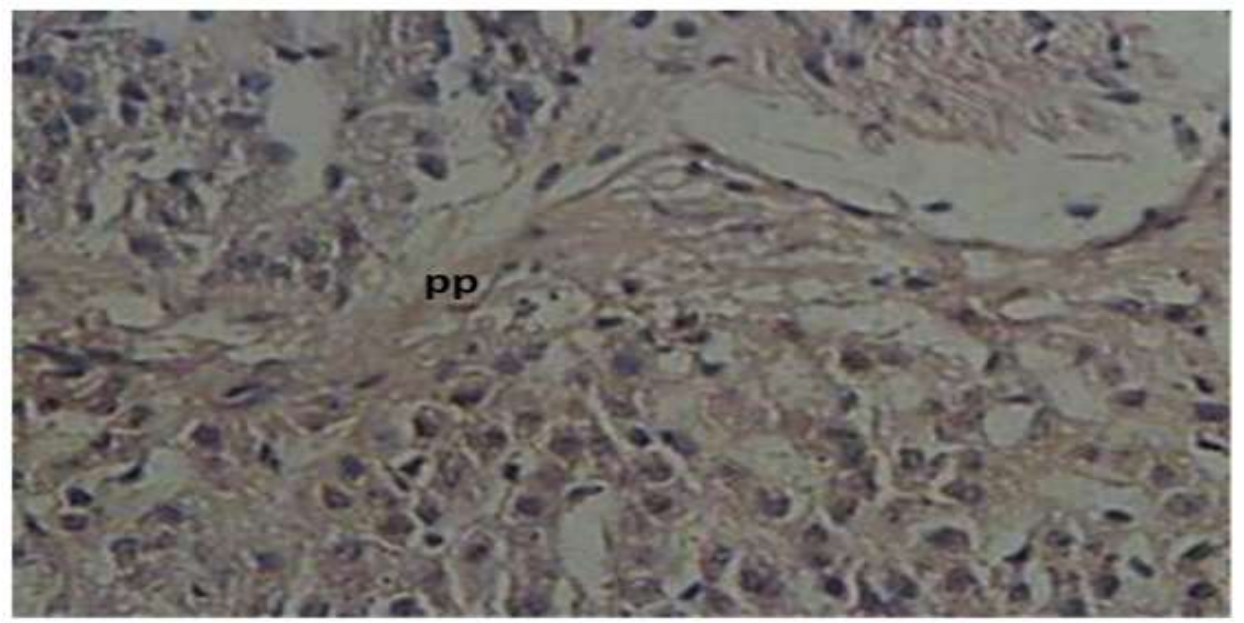

Fig (9): Transverse section of second layer of medulla adrenal gland showed types cells were peripheral position $(400 \mathrm{x})$. H\&E staining.

\section{Discussion}

The current study has demonstrated the histological exploration of glands which were rather complete agreement with that mentioned by (Gartner and Hiatt, 2000) in monkey and (Bacha and Wood, 1993) which referred that the glands have collagenous connective tissue capsule which blood 


\section{University of Thi-Qar Journal Vol. 13 No.3 SEP 2018 \\ Web Site: https://jutq.utq.edu.iq/index.php/main \\ Email: journal@jutq.utq.edu.iq}

vessels and nerves pass through it. Also cortical cells, immediately deep into capsule,zona glomerularis cells are arranged in irregular array forming more or less around clusters. While the results have revealed that there are slightly differences with in zona fasciculate cells in their organization and structural aspects. However, the same authors mentioned that cells of zona fasciculate were larger than of zona glomerulosa that compliance with this study. As well as the results provided subdivision to zona fasciculate cells due to the differentiation of cells in upper part and lower part of this zone. Hence, The considerable division provided cortex further zone that this study confirmed that cortex composed from four zones institute of three zones which is full agreement with (Bacha and Wood, 1990).Many authors referred to foamy appearance present in zona fasciculate cells due to the numerous lipid droplet that were extracted during processing (Tanyola, 1993 and Gartner and Hiatt, 2000) that complete similarity with present study description. The differentiation of zona fasciculate cells into two types attributed to these cells secreted two different materials or hormones as well as it regarded largest zones of cortex. As concerning of zona reticularis cells appeared closely interfering with medullary cells due to the similarity in size between these cells therefore, difficult recognition between them beside that irregular arrangement of zona reticularis cells which surrounded medulla cells that it is different from (Gartner and Hiatt, 2000) mentioned that medullary cells were larger than zona reticularis cells. On other hand similar to description by (Junqueira et al., 1995) which mentioned zona reticularis were freely anastomosing and roughly the same in morphological features at the cells of zona fasciculate, but their nuclei and cytoplasm have darker staining. As the current study was completely complain with (coupland and weakley, 1968; Delman, 1993 and Tanyolac, 1993) that they demonstrated large veins are characteristics of medulla. Medulla cells consist of two types which are similar to each other in size therefore, difficult to distinguished between their structural features that it is attributed to peripheral and central cells which secreted epinephrine and nor epinephrine (Delman, 1993; Steven and Lowe,1991).The results pointed out that medulla description was similar to previous studies (Jureck et al.,1978 and Karadag et al.,1995). As concerning of biometric 


\section{University of Thi-Qar Journal Vol. 13 No.3 SEP 2018 \\ Web Site: https://jutq.utq.edu.iq/index.php/main \\ Email: journal@jutq.utq.edu.iq}

study, the results have been reported that capsule thickness was (250 micrometer)more thick than capsule thickness (25 micrometer) in porcupine (Yilmaz and Girgin,2005),also cortex appeared more thick and low ratio 1720 micrometer as comparison with cortex in porcupine (1491 micrometer) which is formed $73 \%$ as well as the three zones thickness of cortex have reported high measurements than thickness of three zones of cortex in porcupine which were (135).(990) and (366) micrometer respectively. While the results have shown that zona glomerularis was formed $15.56 \%$ which was narrow than zona fasciculate which is formed $27.48 \%$ whereas wider than zona reticularis which is formed $13.90 \%$ that is slightly differences with three zones ratio in porcupine, zona glomerulosa was narrow than zona fasciculate and zona reticularis whatever zona fasciculate was widest in this animal (Yilmaz and Girgin, 2005). Results of this study individual that zona fasciculate appeared 48.25\% of cortex and $27.48 \%$ of the gland which is provided different ratio as comparison with previous studies zona fasciculate formed $60 \%$ of cortex (Tanyolac, 1993) and 70\% of cortex in rabbit (Karaolag et al., 1995). According to (Junqeira et al.,1995) the zona fasciculate in human is $65 \%$ of the gland. The present results identified that medulla formed one of third of gland which is different with ( Junqeira et al.,1995) is $13 \%$ of the human gland where as adrenal gland formed quarter of gland in goat(Jamdar and Ema,1982) as well as in porcupine (Yilmaz and Girgin,2005).

\section{References}

1. Bacha, W.J. \& Wood,M.(1990).Color Atlas of Veterinary Histology.Lea \& Febiger, Philadelphia,pp.178-18.

2. Bank, W.J. (1993).Applied Veterinary Histology, Third ed.,Mossbyyear Book,Philadelphia,pp.416-423.

3. Colby, H.D.,M.Levitt,M.R.Pore and P.B.Jhonson.(1992).Differential effect of aderenocorticotroina hormone on steroid hydroxlase in the inner \& outer zones of the guinea pig adrenal cortex.J.Steriod.Biochem .Mol.,42:329-335. 
Web Site: https://jutq.utq.edu.iq/index.php/main

Email: journal@jutq.utq.edu.iq

4. Coupland, R.E.\& Weakley,B.S.(1968).Developing chromaffin tissue in the rabbit: an electron microscopic study.J.Anat.,102:425-455.

5. Delman, N.D. (1993).Textbook of Veterinary Histology. Four ed., Lea\&Febiger, Philadelphia .pp.280-282.

6. Jamdar,M.N.,Ema,A.N.(1982)Melanin pigment containing cells in the capsule of the adrenal of the goat.Zebl.Vet.Med.C Anat. Histol. Embryo. 11:250-253.

7. Junqueira, L.C.,J.Carneiro and O.R.Kelley (1995).Basic Histolgy.Eight ed., Appleton and Lange,Toronto,pp.387-397.

8. Jurecka, W.,H.Lassman \& H.Horander (1978). The Proliferation Of Adrenal Modularly cells in newborn and adult mice.A light and Microscopic auto radiographic study. Cell Tissue Res., 189:305-312.

9. Gartner, L.P. \& Hiatt,J.L (2006).Color Atlas Of Histology. ${ }^{4}$ ed., Lippincott Williams Wilkins Philadelphia,Pennsylvania.210-211.

10. Gude, W.D.,G.E.Cosgrove and G.P.Hirsch.(1982).Histology atlas of the laboratory Mouse ,Plenum press,New york and London,pp.17-18.

11. Karadag, H.H.S.Yilmaz, H.H.Donmez and I.H.Nur. (1995).Tavsanda ovariektominin adrenal bez uzerinde morfolojik etkileri.F.U. Saglik Bil.Derg., 9165-173.

12. Luna,L.G.(1968).Manual of histologic staining methods of armed forces institute of pathology $3^{\text {rd }}$.New Yok,U.S.A.pp:123.

13. Prasad,G.R. and D.Shina (1981).Micrometric observation on the adrenal glands of domestic animals .Indian J.Anim.Sci.,51,1144- 1147.

14. Petorak I. (1984).Medical Embryology (in Turkish).Stanbul:Osman Aykac Matbaasi,258.

15. Steven, A.and Lowe, J.S. (1991).Histology.Mossby -year Book Europe LTD., London, PP.363-364.

16. Tanyolac, A. (1993).Ozel Histoloji.Yorum Basin Yayin Sanayi LTD., Ankara, pp.162-165.

17. Temur, A.,A.Tli and M.,Kara. (2007).Histologic and Biometric study on the adrenal cortex of cattle BAU FEN BIL.ENS pp.53-60.

18. Williams, PL \& Warwick R.G. (1995). Anatomy. New York: Churchill Livingstone, 1458-1461. 
University of Thi-Qar Journal Vol. 13 No.3 SEP 2018

Web Site: https://jutq.utq.edu.iq/index.php/main

Email: journal@jutq.utq.edu.iq

19.Yilmaz,s.\& Girgin,A.(2005).Light and Electron Microscopic Observations on the porcupine (Hystric cristata) adrenal gland. Veterinarski Arhiv., 75(3):265-272.

\section{الخلاصه}

هدفت الدراسه الحاليه الى دراسه المكونات النسيجيه والنتركيبيه و القياسات البايومنريه للغده الناه

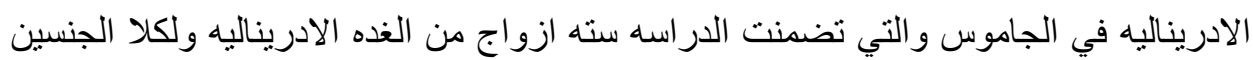

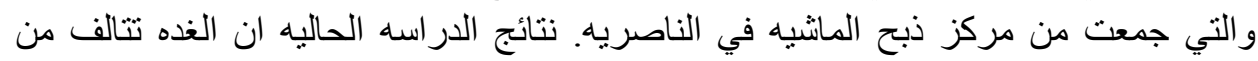

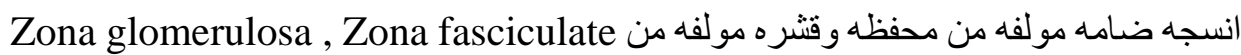
Zona Reticulate حيث ان القشره شكلت اكثر من نصف الغده و القشره شكلت ثلث الغده. 